\title{
Water relations of honey mesquite following severing of lateral roots: influence of location and amount of subsurface water
}

\author{
R.J. ANSLEY, P.W. JACOBY, AND G.J. CUOMO
}

\begin{abstract}
Location and amount of subsurface water may influence the degree of dependence of honey mesquite (Prosopis glandulosa Torr.) on shallow lateral roots to supply water. The objective of this study was to determine influence of lateral roots on water relations of honey mesquite on 2 sites which differed in location and amount of subsurface water. Lateral roots were severed with barriers placed to $1.5 \mathrm{~m}$ depth and completely surrounding individual trees in February 1985, during mesquite winter dormancy. Stomatal conductance and predawn leaf water potential were significantly reduced in root-severed trees during the following growing season (May-September) at both sites, but reduction was greater on the site with less subsurface water. Daytime leaf water potential was higher in root-severed than control trees on the site with less subsurface water, but not on the other site. By midsummer 1986, no difference in stomatal conductance between treatments were detected at either site, yet daytime leaf water potential remained higher in root-severed than control trees at the site with less subsurface water. Predawn leaf water potential was greater in root-severed than control trees in 1986, which was a reversal of 1985 trends. Leaf abscission was not observed in either treatment during either growing season. These results suggest that: (1) when less subsurface water was available, trees were more dependent on lateral roots to supply water, (2) treatment effects were minimized by the second growing season following root severing, possibly from new root growth within or below the root barrier region, and (3) the lateral root system may play a significant role in regulating leaf water relations on sites with limited subsurface water.
\end{abstract}

Key Words: stomatal conductance, leaf water potential, transpiration, soil moisture, Prosopis glandulosa, phreatophyte, Texas

\footnotetext{
Authors are postdoctoral research associate and professor, Texas A\&M University Agricultural Research and Extension Center, P.O. Box 1658, Vernon 76384; and research assistant, Agronomy Dept., University of Nebraska, Lincoln.

Published with the approval of the director, Texas Agricultural Experiment Station as TA-25050. This research was funded in part by a grant from University LandsSurface Interests, Univ. Texas System, Midland; and the E. Paul and Helen Buck Waggoner Foundation, Vernon, Texas.

The authors wish to acknowled ge Cecil Meadors and Keith Lawrence for assistance in data collection. We thank Jim Richards, David Briske, and Ron Sosebee for their review of various drafts of this manuscript.

Manuscript accepted 10 January 1990.
}

In many arid and semiarid regions of the southwestern USA, honey mesquite (Prosopis glandulosa Torr.) have deep tap roots which enable the plant to avoid drought (Phillips 1963, Mooney et al. 1977, Nilsen et al. 1983). These plants are able to maintain stomatal conductance and continue carbon fixation during summer drought (Felker 1979). Under such conditions mesquites have been described as phreatophytes or facultative phreatophytes (Thomas and Sosebee 1978, Nilson et al. 1984).

Mesquite occur throughout the Rolling Plains resource region of north central Texas and encounter conditions characterized by limited subsurface water and intermittently available surface moisture. Summer rainfall from convective storms seldom penetrates below $30 \mathrm{~cm}$ into the soil profile on medium to heavy textured soils and is rapidly depleted by evapotranspiration. Mesquite in this area often have lateral roots which extend well beyond the canopy perimeter (Fisher et al. 1959, Ludwig 1977, Heitschmidt et al. 1988). We hypothesized that differences in location and amount of subsurface water would influence the degree of dependence of this species on shallow lateral roots for water acquisition. The objective of this study was to determine the relative importance of shallow lateral roots to mesquite on sites which vary in amount and location of subsurface water.

\section{Methods and Materials}

\section{Site Description and Preparation}

Research was conducted on 2 sites, Cottonwood and Ninemile, located on the W.T. Waggoner Estate, south of Vernon in the northern Rolling Plains ecological area of Texas (Cottonwood: $33^{\circ} 52 \mathrm{~N}, 99^{\circ} 17^{\prime} \mathrm{W}$, elev. $375 \mathrm{~m}$; Ninemile: $33^{\circ} 51 \mathrm{~N}, 99^{\circ} 26 \mathrm{~W}$, elev. $381 \mathrm{~m}$ ). The sites are $15 \mathrm{~km}$ apart and subject to similar climatic conditions. Mean annual rainfall is $665 \mathrm{~mm}$ with a bimodal distribution. Peak rainfall months are May $(119 \mathrm{~mm})$ and September $(77$ $\mathrm{mm})$. Mean monthly air temperatures range from a maximum of $36^{\circ} \mathrm{C}$ in July to a minimum of $-2.5^{\circ} \mathrm{C}$ in January. Both study sites are dominated by a mesquite and lotebush (Ziziphus obtusifolio [T. and G.] Gray var. obtusifolia) overstory. Understory species include $\mathrm{C4}$ grasses buffalograss (Buchloe dactyloides [Nutt.] Engelm.) and sideoats grama (Bouteloua curtipendula [Michx.] 
Torr.), and the C3 Texas wintergrass (Stipa leucotricha Trin. and Rupr.).

Soils at Cottonwood are fine, mixed thermic Typic Paleustalfs of the Kamay series. These soils are residual in formation and are characterized by clay loam textures to about $1 \mathrm{~m}$ depth, underlain by calcareous sandstone/shale parent material (termed "Permian redbed"). Soils at Ninemile are fine, mixed, thermic Typic Paleustolls of the Tillman series. These soils are also clay loams but are more alluvial in nature than soils at Cottonwood. Parent material does not occur until 3 to $4 \mathrm{~m}$ depth at Ninemile. Due to these factors, permeability below $1 \mathrm{~m}$ depth is less, but potential for saturation of surface horizons is greater at Cottonwood than at Ninemile.

Four multistemmed mesquite trees of similar size were selected for study at each site. The trees averaged $2.9 \mathrm{~m}\left(\mathrm{~s}^{2}=.1\right)$ in height and $4.1 \mathrm{~m}\left(\mathrm{~s}^{2}=.2\right)$ in canopy diameter. In December 1984 , aerial portions of all woody vegetation including nonexperimental mesquite occurring within a $15-\mathrm{m}$ radius of each experimental tree were removed with a chainsaw, and potential for resprouting was eliminated by treating stumps with diesel oil. In February and March 1985, prior to mesquite budbreak, lateral roots of 2 experimental trees on each site were severed by placing a sheet metal barrier vertically to $1.5 \mathrm{~m}$ depth around each tree. The remaining 2 experimental trees at each site were identified as control trees. Descriptions of root severing techniques are published elsewhere (Ansley et al. 1988).

\section{Data Collection}

Stomatal conductance $\left(g_{\mathbf{s}}\right)$ of abaxial leaflet surfaces was measured using a LICOR LI-1600 autoporometer from May to September at both sites during each year. Measurements were made on leaves located between 1.25 and $1.75 \mathrm{~m}$ above ground, and oriented to face the sun. Two leaves per tree were measured during each diurnal sample period which occurred at 2-hour intervals during daylight hours, beginning at 1 hour post sunrise (HPS). Only leaves on the perimeter of the canopy were sampled. All measurements were made on predominantly clear, cloud free days and at least 5 days following precipitation.

Leaf petiole xylem water potential (leaf $\Psi$ ) was measured using a Scholander pressure bomb prior to sunrise (predawn leaf $\Psi$ ) and concurrently with porometer readings (daytime leaf $\Psi$ ) on each sample day, as outlined by Turner (1981). At predawn, 2 leaves were removed from the center of the canopy, and, during the day, duplicate leaves were excised from the sun exposed aspect of each canopy for leaf $\Psi$ measurement. Photosynthetic photon flux den-

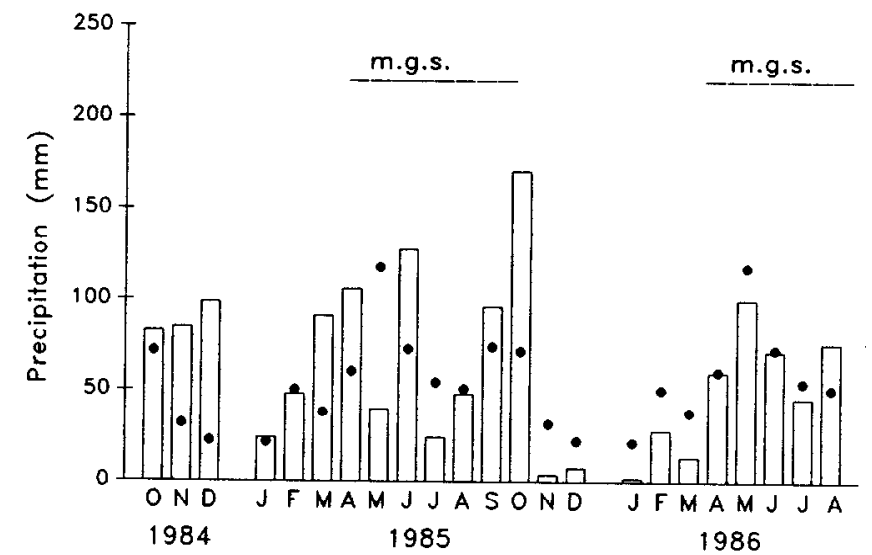

Fig. 1. Monthly precipitation during the duration of the study. A filled circle indicates the 25 -year average for each month. m.g.s. = mesquite growing season. sity (PPFD) $\left(400\right.$ to $700 \mathrm{~nm}$ ) was determined concurrently with $g_{2}$ measurements using a quantum sensor which was mounted to the porometer. Air temperature and relative humidity were recorded with a psychrometer located within $20 \mathrm{~m}$ of the trees at each site. Vapor pressure deficit was calculated from these values. Precipitation was recorded at each site.

Volumetric soil moisture $(\theta)$ was measured using the neutron attenuation device (Graecen 1981). Four aluminum access tubes were inserted to a $1.7 \mathrm{~m}$ depth and located laterally at $2 \mathrm{~m}$ distance from each tree. In root-severed trees, the tubes were located within (tree-side) the root barrier. Measurements were made at $30 \mathrm{~cm}$ depth increments to $150 \mathrm{~cm}$ roughly once every 2 weeks. Soil water retention curves were determined at each site and soil depth using a ceramic pressure plate apparatus (Richards 1965). Soil matric potential (soil $\Psi_{m}$ ) was calculated from $\theta$ using retention curve equations. In 1988, 2 additional access tubes were inserted to a depth of $7 \mathrm{~m}$ near control trees at each site to provide further information regarding subsurface water content.

An analysis of variance design was established with 2 treatments (control and root-severed) and 2 replicates per treatment to assess significant differences in $g_{a}$, leaf $\Psi, \theta$, and soil $\Psi_{m}$ within a particular sample date, diurnal HPS (for plant variables), depth (for soil variables), and site (SAS 1982).

\section{Results}

\section{Climatic Variables}

Monthly precipitation patterns did not vary significantly between sites and data were pooled. Precipitation was near or above normal during both growing seasons (April to October), with the exception that May was very dry in 1985 (Fig. 1). Vapor pressure deficit increased seasonally across both sites and years from lowest values in May to highest values in late August or early September (Fig. 2).

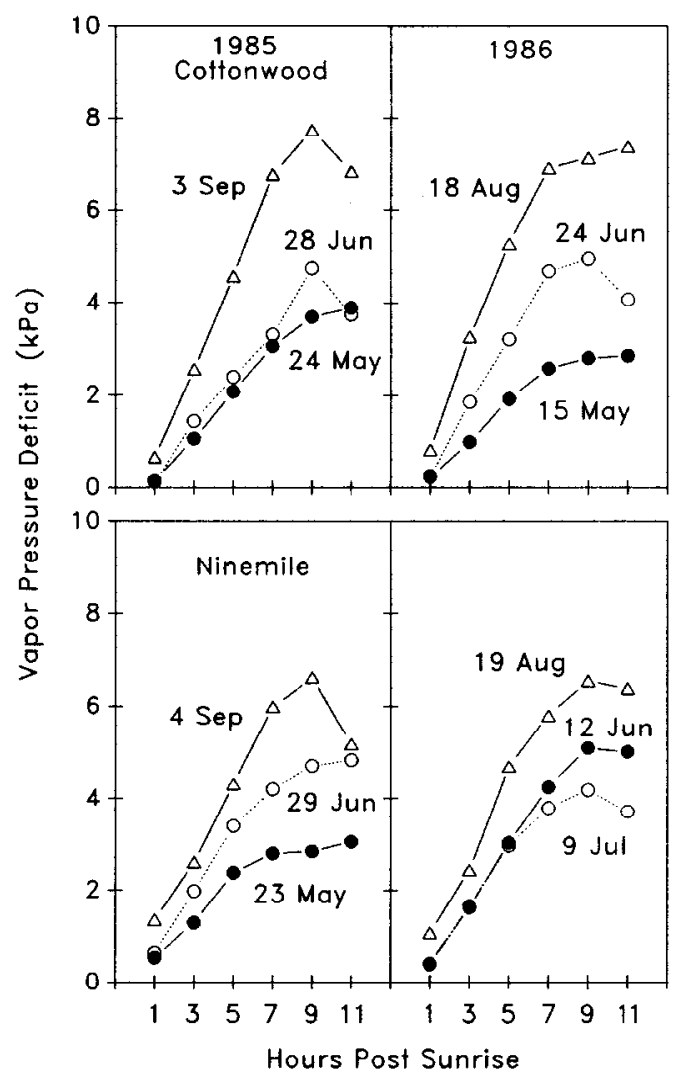

Fig. 2. Diurnal vapor pressure deficits on each of the gample dates at Cottonwood (top) and Ninemile (bottom) in 1985 and 1986. 


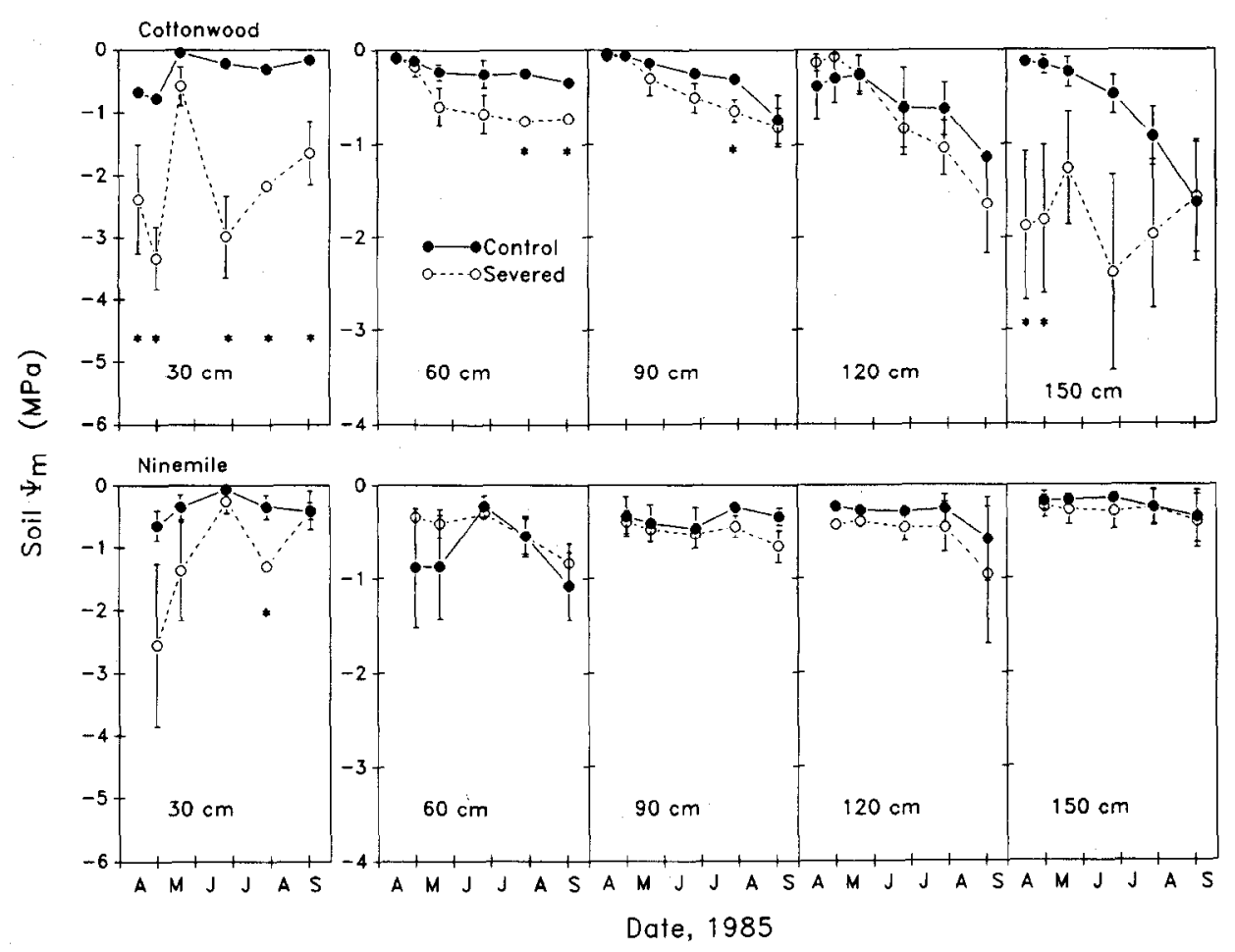

Fig. 3. Soil matric potential at several depths near trees within root barriers (Severed) and at a similar distance from control trees at Cottonwood (top) and Ninemile (bottom) in 1985. An asterisk indicates a significant difference between treatments $(p \leq 0.05)$ at a particular date. Vertical bars indicate \pm 1 S.E.

Vapor pressure deficit was similar between years on comparable dates, except at Cottonwood in May, when it was greater in 1985 than 1986. Diurnal patterns of PPFD were similar for all sample days (data not shown).

\section{Soil Moisture}

Soil matric potential (soil $\Psi_{m}$ ) near control trees at Cottonwood remained above $-0.5 \mathrm{MPa}$ at 30 and $60 \mathrm{~cm}$ depths, but declined progressively to below $-1 \mathrm{MPa}$ at lower depths during the 1985 growing season (Fig. 3). In contrast, soil $\Psi_{m}$ remained near or above $-1 \mathrm{MPa}$ at all depths measured near control trees at Nine-

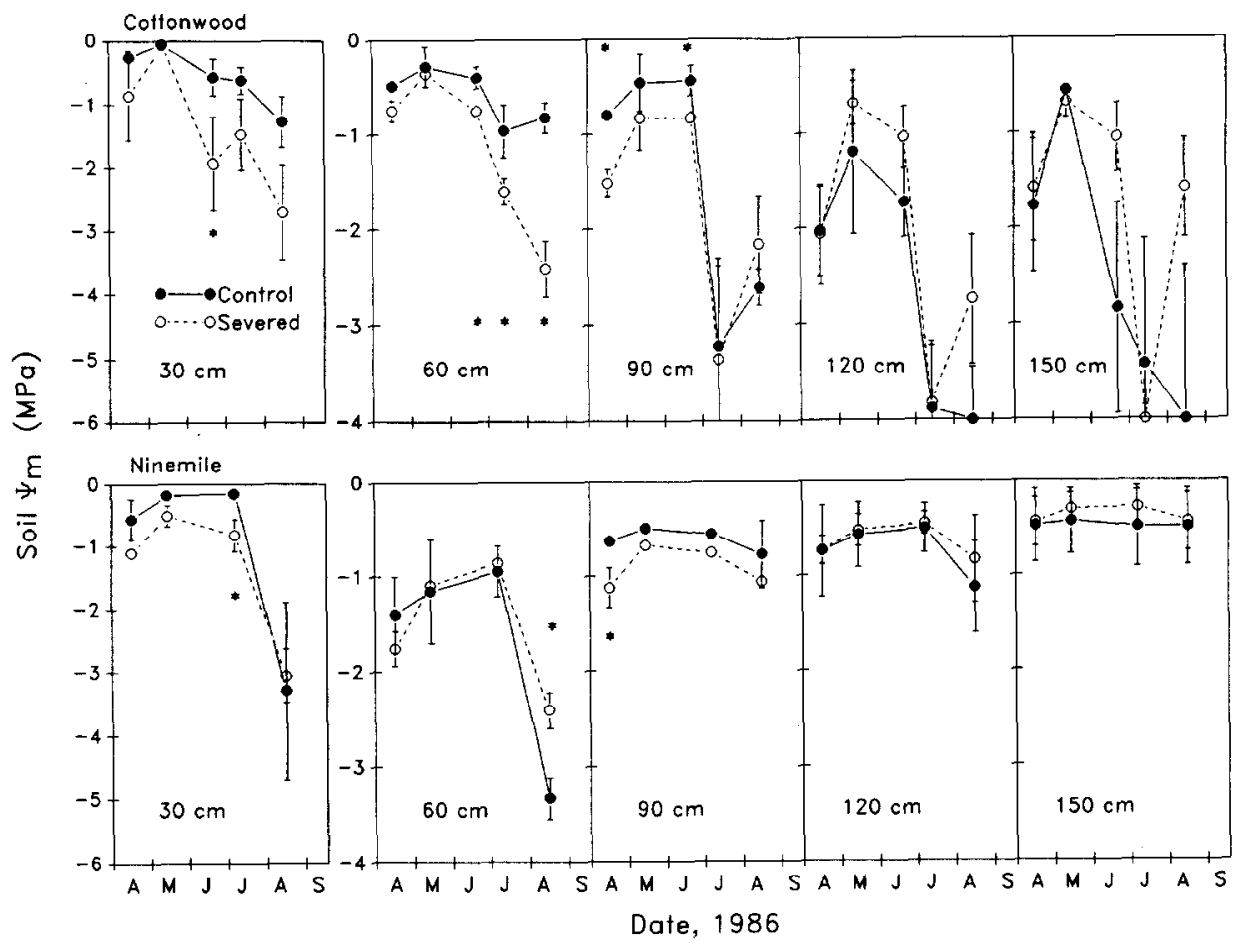

Fig. 4. Soll matric potential at several depths near trees within root barriers (Severed) and at a similar distance from control trees at Cottonwood (top) and Ninemile (bottom) in 1986 . An asterisk indicates a significant difference between treatments $(\leq 0.05)$ at a particular date. Vertical bars indicate \pm 1 S.E. 


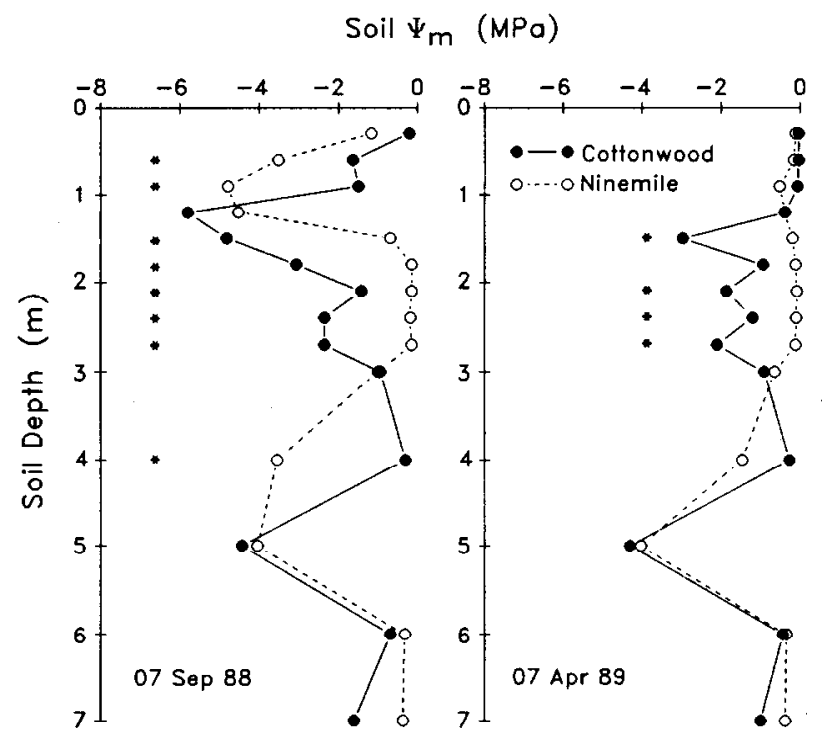

Fig. 5. Subsurface soil matric potential at Cottonwood and Ninemile on 2 dates. An asterisk indicates a significant difference $(p \leq 0.05)$ between sites within a particular date and depth.

mile during 1985 . Soil $\Psi_{\mathrm{m}}$ at $30 \mathrm{~cm}$ depth declined more rapidly within root barriers than at a similar distance from control trees at Cottonwood during 1985. This trend between treatments was also apparent, although to a lesser degree, at $60-120 \mathrm{~cm}$ depths at Cottonwood, and at 30 and $90 \mathrm{~cm}$ depths at Ninemile.

During the 1986 growing season, soil $\Psi_{\mathrm{m}}$ at $60-150 \mathrm{~cm}$ depths near control trees was generally lower than during 1985 at both sites (Figs. 3 and 4). This trend was not observed at $30 \mathrm{~cm}$ depth except during August at Ninemile. Differences in soil $\Psi_{m}$ between years may have been caused by precipitation during nongrowing months (November-March), which was above normal prior to the 1985, but below normal prior to the 1986 growing season (Fig. 1).

Similar to 1985 , soil $\Psi_{\mathrm{m}}$ at 30 and $60 \mathrm{~cm}$ depths declined more rapidly within root barriers than near control trees during 1986 at Cottonwood (Fig. 4). However, differences between treatments were less at the $30 \mathrm{~cm}$ depth and greater at the $60 \mathrm{~cm}$ depth in 1986 than 1985. At Ninemile, relative responses to treatments were similar between years. In both years, differences between treatments were not as pronounced at this site as at Cottonwood.

Deep moisture measurements after a summer drought (in 1988) and a winter recharge (in 1988/89) indicated that from 1.5 to $3 \mathrm{~m}$ depth, soil $\Psi_{\mathrm{m}}$ was consistently and significantly greater at Ninemile than at Cottonwood (Fig. 5). Similar differences between sites were revealed at 120 and $150 \mathrm{~cm}$ depths (Figs. 3 and 4).

\section{Mesquite Phenology and Leaf Area}

Mesquite budbreak occurred in mid-April during both years. Leaves were retained without noticeable abscision in both control and root-severed trees until late October on both sites and during both years (visual observation).

\section{Stomatal Conductance}

Stomatal conductance $\left(g_{\bullet}\right)$ of control trees declined seasonally from May to September, 1985 at both sites (Fig. 6). Diurnally, $g$. tended to decline from morning maximum values on each sample day.

Conductance was significantly greater in control than rootsevered trees during 10 of the 17 HPS measurement periods at Cottonwood in 1985. Root severing reduced $g$, more frequently and to a greater degree at Cottonwood than Ninemile during 1985. During 1986, there were no consistent differences in $g_{\mathrm{a}}$ between

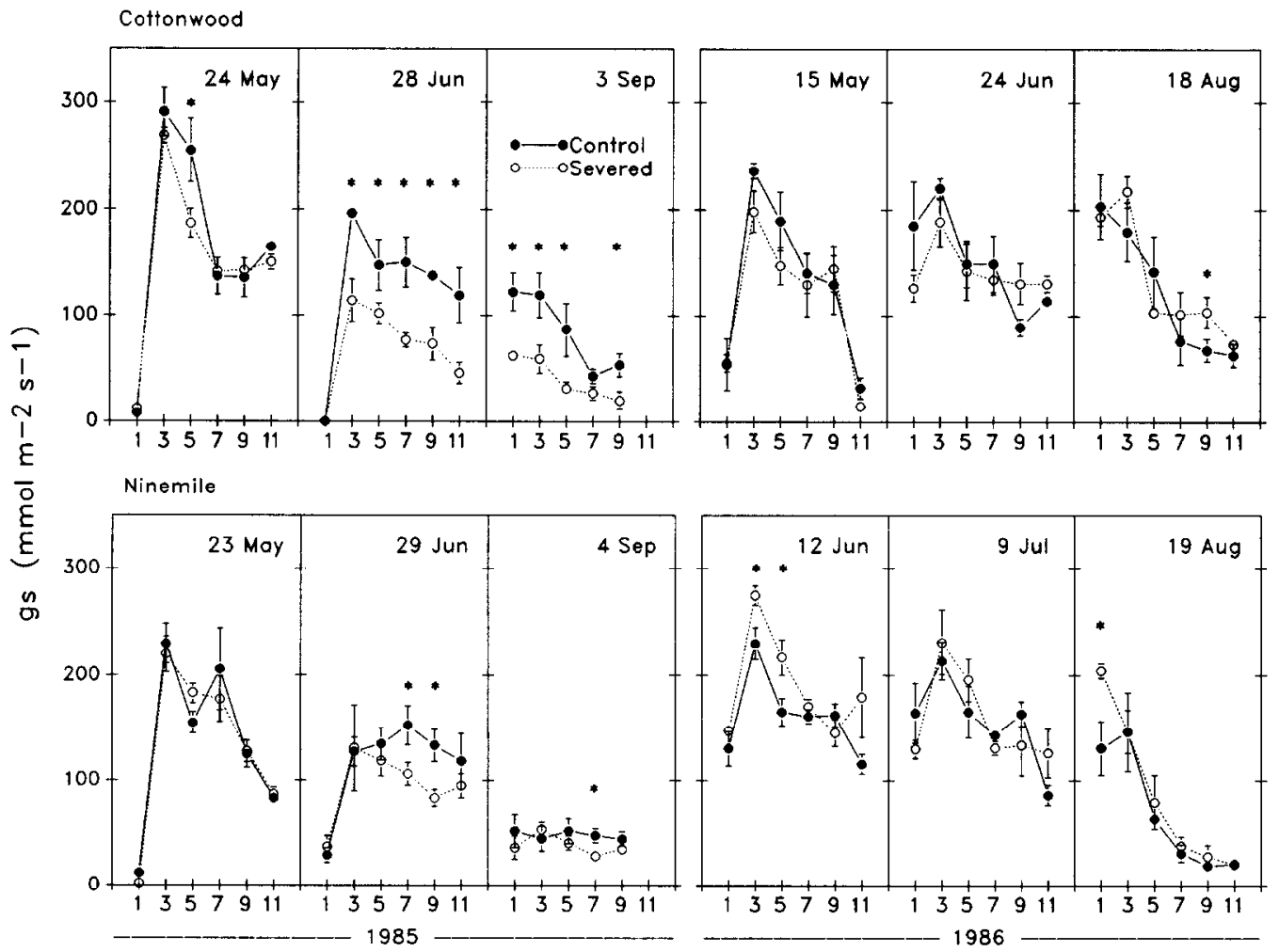

Hours Post Sunrise

Fig. 6. Stomatal conductance $\left(\mathrm{s}_{\mathrm{g}}\right)$ of leaves control and root-severed trees at Cottonwood and Ninemile on several dates in 1985 and 1986 . An asterisk Indicates a significant differences $(p \leq 0.05)$ between treatments at a particular HPS. Vertical bars indicate \pm S.E. 


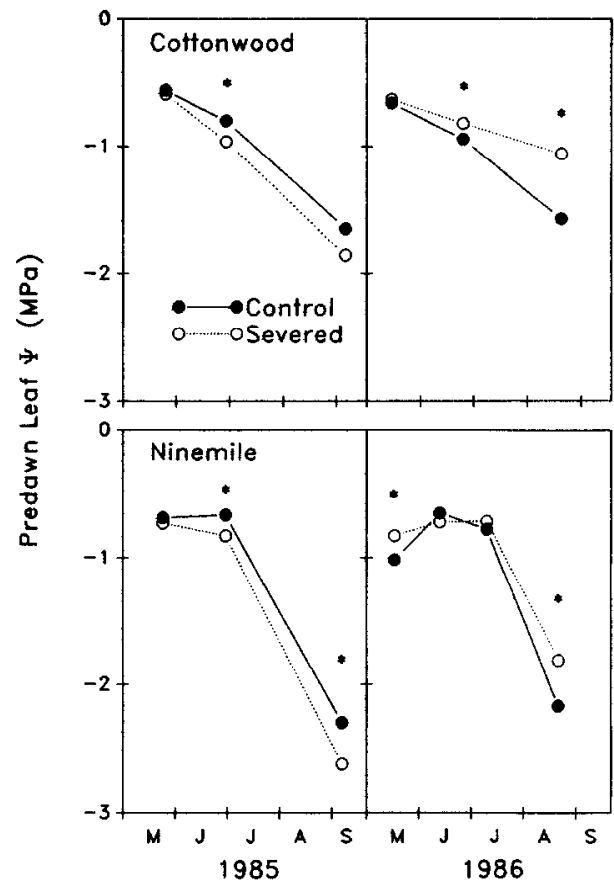

Fig. 7. Predawn leaf water potential of control and root-severed trees at Cottonwood (top) and Ninemile (bottom) in 1985 and 1986. An asterisk indicates a significant difference $(p \leq 0.05)$ between treatments at a particular HPS.

treatments at either site, although $g_{\text {, }}$ of root-severed trees frequently exceeded values of control trees, especially at Ninemile.

\section{Predawn and Daytime Water Potential}

Predawn leaf $\Psi$ was significantly lower in root-severed than control trees during June 1985 at Cottonwood, and June and September 1985 at Ninemile (Fig. 7). In 1986, a reversal of trends occurred in which predawn leaf $\Psi$ was higher in root-severed than control trees after May at Cottonwood, and in May and August at Ninemile. At both sites, predawn leaf $\Psi$ of control trees followed similar trends in each year, and it was responses of root-severed trees that varied.

Minimum daytime leaf $\Psi$ of control trees occurred earlier in the day as the growing season progressed at both sites and during both years (Fig. 8). Moreover, following reduction to minimum daily values, daytime leaf $\Psi$ remained low for a shorter period of time as each growing season progressed. This was probably due to stomata closing earlier in the day in response to seasonally increasing vapor pressure deficit and decreasing soil moisture.

Daytime leaf $\Psi$ was significantly higher in root-severed than control trees at Cottonwood in June and September 1985, and during June and August 1986. In contrast, daytime leaf $\Psi$ was similar between treatments at Ninemile during both years.

\section{Discussion}

The results suggest mesquite at both sites were dependent on water extraction from lateral roots because stomatal activity was retarded in root-severed trees in 1985. Soil moisture was utilized more rapidly within the root barrier than at the same distance from control trees and apparently became limiting by late June 1985 . Reduced $g_{*}$ may also have been the result of an inability of rootsevered trees, with a limited root system, to fully exploit rains which occurred in early June 1985 (Sala and Lauenroth 1982). Root severing did not cause leaf abscission during the growing season of either year but reduction in $g_{\text {s }}$ during June, when demand for water during carbon fixation and growth was seasonally at maximum, created a potential loss to photosynthetic capacity (Wilson et al. 1974, Hanson and Dye 1980, Nilsen et al. 1984). Lower predawn leaf $\Psi$ than control trees during 1985 at both sites

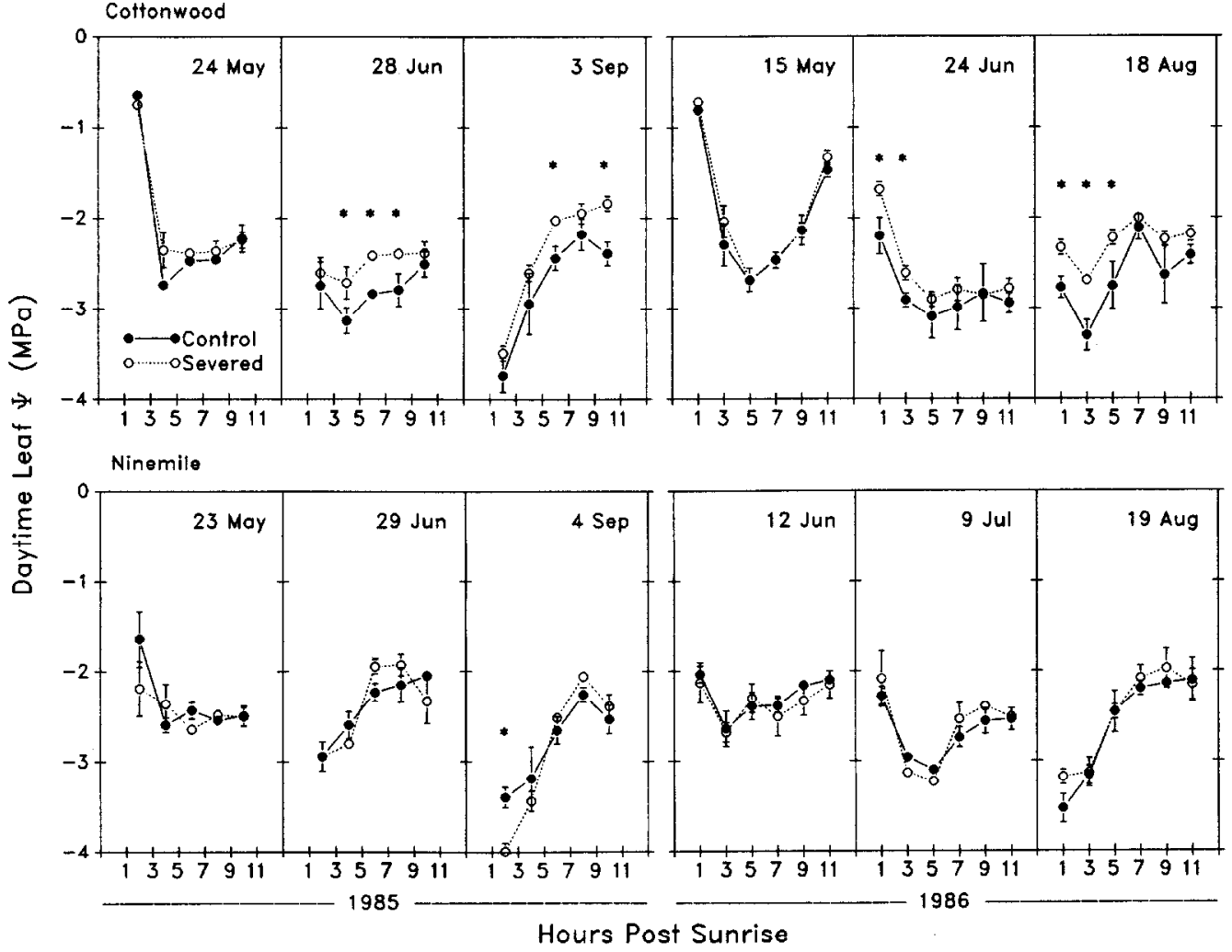

Fig. 8. Daytime leaf water potential of control and root-severed trees at Cottonwood and Ninemile in 1985 and 1986. An asterisk indicates a significant difference $(\boldsymbol{\rho} \leq 0.05)$ between treatments at a particular HPS. Vertical bars indicate \pm 1 S.E. 
was an indication of a reduced ability of root-severed trees to nocturnally recharge aboveground tissue, probably due to reduced root absorption area. Higher daytime leaf $\Psi$ in root-severed than control trees at Cottonwood in 1985 was an indication of tissue recharge following mid-morning stomatal closure. A lower daytime leaf $\Psi$ indicated more, not less, water flux through the soilplant-atmosphere continuum.

These results concur partially with Crombie et al. (1987), who in an Australian study reported root-pruned jarrah (Eucalyptus mar-

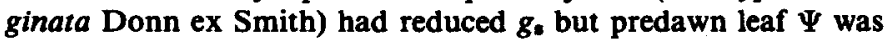
unaffected. Geisler and Ferree (1984) found decreased transpiration following root pruning of apple (Malus domestica) seedlings. They also observed leaf wilting and decreased daytime leaf $\Psi$ in root-pruned plants, which we did not. However, our root pruning occurred prior to budbreak whereas apple Malus was in full leaf when pruned. Severing taproots did not significantly reduce $g_{a}$ in irrigated honey mesquite near Lubbock, Texas (Thomas and Sosebee 1978), supporting the generalization that sufficient lateral roots existed to absorb water when available.

Equalization of $g$. between treatments at both sites in 1986 suggests root-severed trees had recovered from injury. Responses were apparently soil related since vapor pressure deficits were similar between years on comparable mid- to late summer dates. Since leaf area was not reduced in comparison to control trees, root-severed trees may have improved their ability to exploit a limited soil volume through increased root growth. Root-pruned apple seedlings had an increased density of small roots close to the stem (Geisler and Ferree 1984). Other studies have found that following root pruning, assimilates were redistributed to the roots, presumably to facilitate new root growth (Richards and Rowe 1977, Ruff et al. 1987).

Greater predawn leaf $\Psi$ in root-severed than control trees in 1986 implies that nocturnal recharge potential was enhanced in root-severed trees by the second growing season. Since soil moisture was actually less within root containers in 1986 than 1985 , this suggests root-severed trees accessed moisture below the bottom of the container wall.

\section{Differences Between Sites}

Since both sites experienced similar ambient conditions during 1985 and 1986, differences between sites with respect to plant responses may be attributed to differences in root/soil water relations between sites. The observation that virtually all leaf and soil variables measured were affected by root severing to a greater degree at Cottonwood than at Ninemile suggests trees at Cottonwood were more dependent on lateral roots than trees at Ninemile.

Trees at the Cottonwood site encountered an extremely dry layer of soil from about 1 to $2 \mathrm{~m}$ depth. Edaphic conditions for root growth were favorable above this layer, given frequent soil moisture recharge. Results from this study and root distribution data from Heitschmidt et al. (1988) suggest that under natural conditions, these trees preferentially grew extensive, shallow lateral roots instead of tap roots to supply water demands. Since subsurface water was more abundant at Ninemile than at Cottonwood, trees at Ninemile may naturally have had a greater development of a subcanopy roots into deeper soil regions than trees at Cottonwood, and may thus have been able to tolerate pruning of lateral roots more than trees at Cottonwood. A more pronounced difference in predawn leaf $\Psi$ between treatments at Cottonwood than Ninemile during 1986 suggests belowground recovery from root severing via new root growth was greater for trees at Cottonwood than at Ninemile.

\section{Ecological Implications}

The literature has demonstrated that root sensing of soil drought directly influences leaf water relations through abscisic acid pro- duced in the roots (Cornish and Zeevaart 1985, Davies et al. 1987, Zhang et al. 1987). Since responses to root severing were more apparent at Cottonwood than Ninemile, this suggests that on sites with more limiting subsurface water, regulation of leaf water relations may be related more to soil moisture conditions in interspaces between trees than beneath the tree canopy.

It would be advantageous for trees on sites that had less subsurface water, such as at Cottonwood, to have lateral roots in interspaces which could sense soil drought and regulate stomata, thereby conserving utilization of subcanopy moisture. This would be especially effective should soils of interspaces dehydrate at a more rapid rate than soils beneath the tree canopy. Conversely, where deep water was more available, such as at Ninemile, regulation of stomata may be controlled to a greater degree by subcanopy roots, since no consistent differences in daytime leaf $\Psi$ or $g_{0}$ between control and root-severed trees were observed at this site. Subtle differences in water uptake strategies, based on differences in location and amount of subsurface water, could explain why mesquite persists on a variety of sites.

\section{Literature Cited}

Ansley, R.J., P.W. Jacoby, and B.K. Lawrence. 1988. Root containerization for physiological studies of shrubs and trees on rangeland. J. Range Manage. 41:90-91.

Cornish, K., and J.A.D. Zeevart. 1985. Abscisic acid accumulation by roots of Xanthium strumarim L. and Lycopersicon esculentum Mill. in relation to water stress. Plant Physiol. 79:653-658.

Crombie, D.S., J.T. Tippett, and D.J. Gorddard. 1987. Water relations of root-pruned jarrah (Eucalyptus marginata Donn ex Smith) saplings. Aust. J. Bot. 35:653-663.

Davies, W.J., J.C. Metcalfe, U. Schurr, G. Taylor, and J. Zhang. 1987. Hormones as chemical signals involved in root to shoot communication of effects of changes in the soil environment. p 201-216. In: G.B. Hood, M.V. Jackson, J.R. Lenton, and R. Atkin (eds) Hormone action in plant development-A critical appraisal. Butterworths, London.

Felker, P. 1979. Mesquite: an all-purpose leguminous arid land tree. p. 89-132 In: Ritchie GA (ed) New agricultural crops. Amer. Assoc. Advanc. Sci., Westview Press, Boulder, Colo.

Fisher, C.E., C.H. Meadors, R. Behrens, E.D. Robinson, P.T. Marion, and H.L. Morton. 1959. Control of mesquite on grazing lands. Texas Agr. Exp. Sta. Bull. 935, Texas A\&M Univ., College Station.

Geisler, D., and D.C. Ferree. 1984. The influence of root pruning on water relations, net photosynthesis, and growth of young 'Golden Delicious' apple trees. J. Amer. Soc. Hort. Sci. 109:827-831.

Greacen, E.L. 1981. Soil water assessment by the neutron method. CSIRO, Australia.

Hanson, J.D., and A.J. Dye. 1980. Diurnal and seasonal patterns of photosynthesis of honey mesquite. Photosynthetica 14:1-7.

Heitschmidt, R.K, R.J. Ansley, S.L. Dowhower, P.W. Jacoby, and D.L. Price. 1988. Some observations from the excavation of honey mesquite root systems. J. Range Manage. 41:227-231.

Ludwig, J.A. 1977. Distributional adaptation of root systems in desert environments. p. 85-91. In: J.E. Marshall (ed.), The belowground ecosystem: A synthesis of plant-associated processes. Range Sci. Dept., Colorado State Univ., Ser. 26, Fort Collins, Colo.

Mooney, H.A., B.B. Simpson, and O.T. Solbrig. 1977. Phenology, morphology, physiology. Chap 2, p. 26-41. In: B.B. Simpson (ed.), Mesquite-Its biology in two desert ecosystems. US/IBP Synthesis Ser. 4, Dowden, Hutchinson and Ross, Inc., Stroudsburg, Penn.

Nilsen, E.T., M.R. Sharifi, P.W. Rundel, W. Jarrell, and R.A. Virginia. 1983. Diurnal and seasonal water relations of the desert phreatophyte Prosopis glandulasa (honey mesquite) in the Sonoran desert of California. Ecology 64:1381-1393.

Nilsen, E.T., M.R. Sharif, and P.W. Rundel. 1984. Comparative water relations of phreatophytes in the Sonoran desert of California. Ecology 65:767-778.

Phillips, W.S. 1963. Depth of roots in soil. Ecology 44:424.

Richards, D., and R.N. Rowe. 1977. Root-shoot interactions in peach: the function of the root. Ann. Bot. 41:1211-1216.

Richards, L.A. 1965. Physical condition of water in soil. p. 128-152. In Methods of soil analysis. Amer. Soc. Agron. Mono. 9. 
Ruf,, M.S., D.T. Krizek, R.M. Mirecki, and D.W.Inouye. 1987. Restricted root zone volume: influence on growth and development of tomato. J. Amer. Soc. Hort. Sci. 112:763-769.

Sala, O.E., and W.K. Lauenroth. 1982. Small rainfall events: An ecological role in semiarid regions. Oecologia 53:301-304.

SAS. 1982. SAS users guide: basics. SAS Institute, Cary, N.C.

Thomas, G.W., and R.E. Sosebee. 1978. Water relations of honey mesquite-a facultative phreatophyte. Proc. 1st Int. Rangel. Congr., Soc. Range Manage., Denver, Colo., p. 414-418.
Turner, N.C. 1981. Techniques and experimental approaches for the measurement of plant water status. Plant and Soil 58:339-366.

Wilson, R.T., D.R. Krieg, and B.E. Dahl. 1974. A physiological study of developing pods and leaves of honey mesquite. J. Range Manage. 27:201-203.

Zhang, J., U. Schurr, and W.J. Davies. 1987. Control of stomatal behavior by abscisic acid which apparently originates in the roots. J. Exp. Bot. 38:1174-1181. 